\title{
Analysis of Facility and Home Isolation Strategies in COVID I 9 Pandemic: Evidences from Jodhpur, India [Corrigendum]
}

\author{
Bhardwaj P, Joshi NK, Gupta MK, et al. Infect Drug \\ Resist. 2021;14:2233-2239.
}

Page 2233, Introduction, second paragraph, third sentence, the text "According to the Centers for Disease Control and Prevention (CDC), Isolation is the "separation and restriction of movement of persons, who, while not yet ill, have been exposed to an infectious agent and therefore may become infectious"." should read "According to the Centers for Disease Control and Prevention (CDC), "isolation refers to the separation of persons who have a specific infectious illness from those who are healthy and the restriction of their movement to stop the spread of that illness"."

The authors apologize for this error.

\section{Publish your work in this journal}

Infection and Drug Resistance is an international, peer-reviewed openaccess journal that focuses on the optimal treatment of infection (bacterial, fungal and viral) and the development and institution of preventive strategies to minimize the development and spread of resistance. The journal is specifically concerned with the epidemiology of antibiotic resistance and the mechanisms of resistance development and diffusion in both hospitals and the community. The manuscript management system is completely online and includes a very quick and fair peerreview system, which is all easy to use. Visit http://www.dovepress.com/ testimonials.php to read real quotes from published authors. 